\title{
ДИНАМІКА ЕНЗИМНОЇ ЛАНКИ АНТИОКСИДАНТНОГО ЗАХИСТУ ПІД ВПЛИВОМ ІШЕМІЇ-РЕПЕРФУЗІЇ КІНЦІВКИ, ГОСТРОЇ КРОВОВТРАТИ ТА ПЕРЕЛОМУ НИЖНЬОЇ ЩЕЛЕПИ
}

Вступ. У сучасному світі значно зросла поширеність вогнепальних уражень, ускладнених гострою крововтратою з кінцівок. Застосування за цих умов кровоспинного джгута з максимальним терміном на 2 год належить до основних заходів порятунку поранених на полі бою. У структурі вогнепальних уражень, попри поранення кінцівок, суттєво підвищилась частота ушкоджень лицевої частини черепа з переважним ушкодженням нижньої щелепи. У патогенезі системних проявів зазначених уражень провідну роль відіграє посилення процесів ліпідної пероксидації. Однак вплив ішемії-реперфузії кінцівки, гострої крововтрати і перелому нижньої щелепи на стан ензимної ланки антиоксидантного захисту в печінці вивчено недостатньо.

Мета дослідження - з'ясувати вплив гострої крововтрати, двогодинної ішемії кінцівки і травми нижньої щелепи на динаміку порушень ензимної ланки антиоксидантного захисту в печінці у реперфузійний період.

Методи дослідження. Експерименти виконано на 146 нелінійних щурах-самцях масою 200-220 г. Усіх тварин поділили на 5 груп: контрольну і 4 дослідних. Під тіопентал-натрієвим наркозом у 1-й дослідній групі щурам моделювали ішемію-реперфузію кінцівки, у 2-й-гостру крововтрату (20 \% від об'єму циркулюючої крові), у 3-й - ці ураження поєднували, у 4-й групі тваринам із гострою крововтратою та ішемією-реперфузією кінцівки додатково моделювали перелом нижньої щелепи. Через 2 і 3 год, а також через 1, 7 та 14 діб щурів виводили з експерименту й у печінці визначали активність супероксиддисмутази і каталази.

Результати й обговорення. Двогодинна ішемія кінцівки в реперфузійний період супроводжувалась суттєвим зменшенням активності супероксиддисмутази з максимумом через 1 добу, яка поверталась до рівня контрольної групи через 14 діб. Водночас у всі терміни спостереження підвищеною була активність каталази, що мало компенсаторний характер і свідчило про появу в печінці активних фрорм оксигену. За умов гострої крововтрати активність ензимів антиоксидантного захисту в печінці істотно знижувалась уже через 2 год експерименту, досягала мінімуму через 1 добу і зростала до 14-ї доби, проте не досягала рівня контрольної групи. Додаткове моделювання ішемії-реперфузії кінцівки на тлі гострої крововтрати супроводжувалось найбільшим зменшенням величин супероксиддисмутази і каталази в печінці у всі терміни спостереження, що вказувало на нашарування патогенних механізмів обох втручань та свідчило про значне посилення прооксидантних механізмів, викликане гіпоксією органа. Додаткове моделювання перелому нижньої щелепи на тлі гострої крововтрати й ішемії-реперфузії кінцівки супроводжувалось поглибленням порушень ензимної ланки антиоксидантного захисту в печінці. Відмічали суттєво меншу активність супероксиддисмутази через 1 добу і каталази через 1 та 7 діб порівняно з тваринами, яким моделювали гостру крововтрату й ішемію-реперфузію кінцівки, що вказувало на вагому патогенну роль травми нижньої щелепи у виснаженні антиоксидантного захисту на системному рівні й вимагало розробки патогенетично обґрунтованих засобів корекції.

Висновок. Перелом нижньої щелепи поглиблює тяжкість системних порушень, зумовлених гострою крововтратою та ішемією-реперфузією кінцівки, одним із проявів яких є суттєво більше виснаження ензимної ланки антиоксидантного захисту в печінці через 1 і 7 діб, яке не досягає рівня контрольної групи до 14-ї доби.

КЛЮЧОВІ СЛОВА: перелом нижньої щелепи; крововтрата; джгут; ішемія; реперфузія; печінка; антиоксидантний захист.

ВСТУП. Однією з актуальних проблем XXI ст. $€$ зростання частоти локальних збройних конфрліктів і терористичних атак. За цих умов основною причиною загибелі постраждалих і поранених $€$ гостра крововтрата [1]. Ефективнішим

(ㄱ. І. І. Горбань, А. А. Гудима, О. Г. Нецюк, М. А. Пасічник, 2021. засобом зупинки масивної зовнішньої кровотечі з кінцівок визнано накладання джгута, який повністю припиняє артеріальний кровотік з безпечним терміном до 2 год [2].

У структурі вогнепальних уражень, попри поранення кінцівок, останнім часом значно зросла частота ушкоджень лицевої частини черепа, 
яка залишається найменш захищеною частиною тіла комбатантів. За даними літератури, у конфрлікті на Сході України частота уражень голови і шиї у структурі санітарних втрат становить 39$40 \%$ [3]. При таких травмах у 31,8 \% випадків трапляються ураження обличчя і лицевого скелета [4].

Водночас і за умов небойової травми щелепно-лицевої ділянки в 72-91 \% випадків виникають переломи нижньої щелепи, які бувають переважно у працездатного населення віком від 18 до 45 років [5, 6].

На сьогодні встановлено, що двогодинне повне знекровлення кінцівки зумовлює ушкодження нервів і судин під джгутом, міонекроз, рабдоміоліз, тромбоз глибоких вен [7]. У роботах окремих авторів показано, що ще більші порушення в м'яких тканинах кінцівки та на системному рівні настають після її реперфузії $[8,9]$. Потрапляючи в системний кровотік, токсини 3 ішемізованої кінцівки можуть спричинити метаболічний ацидоз, гіперкаліємію і міоглобінемію [10], накопичення в гомогенатах м'язів, внутрішніх органів та плазмі крові супероксид-радикала [11], зниження загального антиоксидантного захисту [12], збільшення утворення прозапальних цитокінів [13].

У роботах ряду авторів переконливо показано, що пусковим моментом системних порушень за умов гострої крововтрати, ішемії-реперфузії кінцівки і механічної травми є розвиток гіпоксії, посилене утворення активних фрорм оксигену та активація процесів ліпідної пероксидації у внутрішніх органах, що призводить до деградації клітинних мембран, цитолітичного синдрому, поглиблення ендогенної інтоксикації та посиленого утворення медіаторів запалення. Усе це замикає чергове «хибне» патологічне коло, що може спричинити розвиток синдрому системної відповіді організму на запалення 3 розвитком поліорганної дисорункції і недостатності [3, 14-16].

Інтенсивність ліпідної пероксидації під впливом патогенних чинників контролюється антиоксидантним захистом. Однак вплив ішемії-реперсрузії кінцівки, гострої крововтрати і перелому нижньої щелепи на активність антиоксидантного захисту вивчено недостатньо. Немає даних щодо порушень за цих умов ензимної ланки, ключовими фрерментами якої $€$ супероксиддисмутаза (СОД) і каталаза, що забезпечують перший рубіж захисту від токсичного впливу активних фрорм оксигену.

Мета дослідження - з'ясувати вплив гострої крововтрати, двогодинної ішемії кінцівки і травми нижньої щелепи на динаміку порушень ензимної ланки антиоксидантного захисту в печінці у реперфузійний період.
МЕТОДИ ДОСЛІДЖЕННЯ. Експерименти виконано на 146 нелінійних щурах-самцях масою 200-220 г з дотриманням правил Європейської конвенції про захист хребетних тварин, що використовуються для дослідних та інших наукових цілей (Страсбург, 1986). Комісія з біоетики Тернопільського національного медичного університету імені І. Я. Горбачевського МОЗ України проведені експерименти визнала такими, що відповідають основним етичним нормам роботи з лабораторними тваринами (№ 54 від 27.08.2019 р.).

Усіх тварин поділили на 5 груп: контрольну і 4 дослідних. До 1-ї дослідної групи ввійшли 30 щурів, яким моделювали ішемію-реперорузію кінцівки. Під тіопентал-натрієвим наркозом (40 мг·к $\Gamma^{-1}$ маси тварини) щурам проксимально на ліву лапку накладали смужку еластичного джгута "SWAT-T" (США) шириною 10 мм на 120 хв. Джгут затягували відповідно до нанесеного на нього індикатора ефективного тиску, який припиняє кровотік. Знекровлення кінцівки додатково підтверджували реографрічним методом. У 2-й дослідній групі (30 тварин) за умов тіопентал-натрієвого наркозу моделювали гостру крововтрату шляхом пересікання стегнової вени. Після доведення обсягу крововтрати до 20 \% об'єму циркулюючої крові щурам забезпечували гемостаз. У 3-й дослідній групі (30 тварин) ці ушкодження поєднували. У 4-й дослідній групі (50 щурів) на тлі гострої крововтрати й ішемії-реперфузії кінцівки додатково моделювали перелом нижньої щелепи зліва [17]. У ділянці нижньої щелепи за умов асептики й антисептики робили розріз шкіри, відсепаровували м'які тканини та кістковими щипцями наносили перелом у ділянці на 5 мм допереду від кута щелепи. Рану шкіри зашивали капроновими нитками.

Тварин контрольної групи вводили в наркоз, застосовуючи еквівалентну дозу тіопентал-натрію, накладали їм джгут на 2 год без припинення кровотоку, в подальшому брали для досліджень через 1 год.

Через 2 і 3 год, а також через 1, 7 та 14 діб піддослідних тварин під наркозом виводили 3 експерименту методом тотального кровопускання із серця. У гомогенаті печінки визначали активність ключових компонентів ензимної ланки антиоксидантного захисту - супероксиддисмутази [18] і каталази [19].

Вірогідність відмінностей між експериментальними групами оцінювали з використанням непараметричного критерію Манна - Уїтні.

РЕЗУЛЬТАТИ Й ОБГОВОРЕННЯ. АНаліЗ показників антиоксидантної системи показав, що активність СОД у печінці (табл. 1) під впливом ішемії-реперфузії кінцівки, порівняно з контроль- 
ною групою, знижувалася, причому через 3 год й 1 добу результат виявився статистично значущим (відповідно, на 36,8 і 21,5 \%, р<0,05). У подальшому показник зростав i, починаючи із 7-ї доби, досягав рівня контрольної групи ( $>>0,05)$ та був істотно вищим порівняно з 3 год спостереження $(p<0,05)$.

Після моделювання гострої крововтрати показник статистично вірогідно знижувався, порівняно $з$ контрольною групою, в усі терміни спостереження: через 2 год - на 22,5\%, через 3 год - на 46,9 \%, через 1 добу - на 33,1 \%, через 7 діб - на 30,7 \%, через 14 діб - на 40,4 \% ( $<<0,05)$. Як видно, він досягав мінімуму через 1 добу спостереження, що виявилося істотно меншим порівняно 32 год спостереження ( $p<0,05)$. До 14-ї доби показник зростав і статистично вірогідно перевищував результати 2 год й 1-ї доби спостереження $(p<0,05)$.

За умов гострої крововтрати, ускладненої ішемією-реперфузією кінцівки, порушення активності СОД виявилися ще більшими. Показник досягав мінімуму через 1 добу і був на 76,5 \% меншим порівняно 3 контрольною групою $(p<0,05)$, а також із попередніми термінами спостереження $(p<0,05)$. До 14-ї доби він зростав, істотно перевищуючи 2 і 3 год спостереження $(p<0,05)$, проте залишався на 35,8 \% нижчим, ніж у контрольній групі $(p<0,05)$.
Порівняння дослідних груп між собою показало, що після моделювання гострої крововтрати (2-га дослідна група) активність СОД у всі терміни спостереження була статистично вірогідно нижчою, ніж після моделювання лише ішемії-реперфузії кінцівки (1-ша дослідна група) $\left(p_{1-2}<0,05\right)$. Після нанесення гострої крововтрати, ускладненої ішемією-реперфузією кінцівки (3-тя дослідна група), показник у всі терміни спостереження був істотно меншим, ніж у 1-й дослідній групі $\left(p_{1-3}<0,05\right)$, а також через 1, 3 і 7 діб спостереження порівняно 3 2-ю дослідною групою $\left(p_{2-3}<0,05\right)$.

У свою чергу, моделювання гострої крововтрати й ішемії-реперфузії кінцівки в поєднанні $з$ переломом нижньої щелепи через 2 год експерименту, порівняно з контрольною групою, викликало зниження активності СОД на 39,5\%, через 3 год - на 64,1 \%, через 1 добу - на 74,1 \%, через 7 діб - на 70,3 \%, через 14 діб - на 61,0\% $(\mathrm{p}<0,05)$. У динаміці показник досягав мінімуму через 1 й 7 діб експерименту і був істотно меншим порівняно з попередніми термінами спостереження $(p<0,05)$. Через 14 діб він зростав і був суттєво більшим порівняно 32 год, 1-ю і 7-ю добами експерименту ( $p<0,05)$.

Порівняння дослідних груп між собою показало, що в усі терміни спостереження активність СОД у печінці була меншою у тварин з додатко-

Таблиця 1 - Активність супероксиддисмутази в печінці (ум. од.' мг-1) після ішемії-реперфузії кінцівки, гострої крововтрати і перелому нижньої щелепи (Me (LQ; UQ)) - медіана (нижній та верхній квартилі)

\begin{tabular}{|c|c|c|c|c|c|}
\hline \multirow{2}{*}{ Дослідна група } & \multicolumn{5}{|c|}{ Термін реперфузійного періоду } \\
\hline & 2 год & 3 год & 1-ша доба & 7-ма доба & 14-та доба \\
\hline \multicolumn{6}{|c|}{ Контроль $=0,209(0,197 ; 0,220)(n=6)$} \\
\hline $\begin{array}{l}\text { 1-ша (ішемія- } \\
\text { реперфрузія) }\end{array}$ & $\begin{array}{c}0,193 \\
(0,188 ; 0,217) \\
(n=6)\end{array}$ & $\begin{array}{c}0,132^{\star} \\
(0,125 ; 0,142) \\
(n=6)\end{array}$ & $\begin{array}{c}0,164^{\star 2 \Gamma} \\
(0,152 ; 0,170) \\
(n=6)\end{array}$ & $\begin{array}{c}0,187^{3 r} \\
(0,175 ; 0,201) \\
(n=6)\end{array}$ & $\begin{array}{c}0,210^{3 r, 1 A} \\
(0,192 ; 0,227) \\
(n=6)\end{array}$ \\
\hline $\begin{array}{l}\text { 2-га (гостра } \\
\text { крововтрата) }\end{array}$ & $\begin{array}{c}0,162^{*} \\
(0,148 ; 0,166) \\
(n=6)\end{array}$ & $\begin{array}{c}0,111^{* 2 r} \\
(0,099 ; 0,117) \\
(n=6)\end{array}$ & $\begin{array}{c}0,098^{* 2 \Gamma} \\
(0,088 ; 0,106) \\
(n=6)\end{array}$ & $\begin{array}{c}0,103^{* 2 r} \\
(0,097 ; 0,113) \\
(n=6)\end{array}$ & $\begin{array}{c}0,125^{\star 2,1 A} \\
(0,111 ; 0,132) \\
(n=6)\end{array}$ \\
\hline $\begin{array}{l}\text { 3-тя (ішемія- } \\
\text { реперфузія+гостра } \\
\text { крововтрата }\end{array}$ & $\begin{array}{c}0,140^{\star} \\
(0,133 ; 0,150) \\
(n=6)\end{array}$ & $\begin{array}{c}0,108^{* 2 \Gamma} \\
(0,103 ; 0,114) \\
(n=6)\end{array}$ & $\begin{array}{c}0,070 * 2 r, 3 r \\
(0,066 ; 0,077) \\
(n=6)\end{array}$ & $\begin{array}{c}0,068^{* 2 r, 3 r} \\
(0,066 ; 0,075) \\
(n=6)\end{array}$ & $\begin{array}{c}0,072^{\star 2,3 r} \\
(0,059 ; 0,085) \\
(n=6)\end{array}$ \\
\hline $\begin{array}{l}\text { 4-та (ішемія- } \\
\text { реперфузія+гостра } \\
\text { крововтрата+перелом } \\
\text { щелепи }\end{array}$ & $\begin{array}{c}0,127^{\star} \\
(0,118 ; 0,143) \\
(n=10)\end{array}$ & $\begin{array}{c}0,096 * 2 r \\
(0,088 ; 0,108) \\
(n=9)\end{array}$ & $\begin{array}{c}0,050 * 2 r, 3 r \\
(0,046 ; 0,059) \\
(n=7)\end{array}$ & $\begin{array}{c}0,062^{* 2 r, 3 r} \\
(0,052 ; 0,069) \\
(n=7)\end{array}$ & $\begin{array}{c}0,082^{\star 2,, 1 д, 7 д} \\
(0,074 ; 0,087) \\
(n=6)\end{array}$ \\
\hline$p_{1-2}$ & $<0,05$ & $>0,05$ & $<0,05$ & $<0,05$ & $<0,05$ \\
\hline$p_{1-3}$ & $<0,05$ & $<0,05$ & $<0,05$ & $<0,05$ & $<0,05$ \\
\hline$p_{2-3}$ & $>0,05$ & $>0,05$ & $<0,05$ & $<0,05$ & $<0,05$ \\
\hline$p_{3-4}$ & $>0,05$ & $>0,05$ & $<0,05$ & $>0,05$ & $>0,05$ \\
\hline
\end{tabular}

Примітки. Тут і в таблиці 2:

1. * - відмінності стосовно контрольної групи статистично вірогідні $(p<0,05)$.

2. $\mathrm{p}_{1-2}$ - вірогідність відмінностей між 1-ю і 2-ю дослідними групами.

3. $\mathrm{p}_{1-3}$ - вірогідність відмінностей між 1-ю і 3-ю дослідними групами.

4. $\mathrm{p}_{2-3}$ - вірогідність відмінностей між 2-ю і 3-ю дослідними групами.

5. $\mathrm{p}_{3-4}$ - вірогідність відмінностей між 3-ю і 4-ю дослідними групами

6. 2г,3г,1д,7д - відмінності стосовно 2 і 3 год, а також 1-ї та 7-ї діб експерименту статистично вірогідні (р<0,05). 
во змодельованим переломом нижньої щелепи, проте результат виявився статистично значущим через 1 добу (на 28,6 \%, $p_{3-4}<0,05$ ).

У свою чергу, активність каталази (табл. 2) після моделювання лише ішемії-реперфузії кінцівки зростала вже через 2 год експерименту (в 3,64 раза, p<0,05). У подальшому показник продовжував збільшуватись і через 1 добу досягав максимуму (в 6,38 раза, $p<0,05)$ й істотно перевищував попередні терміни спостереження $(p<0,05)$. Через 7 і 14 діб він знижувався, проте не досягав рівня контрольної групи. Через 14 діб показник продовжував перевищувати контроль (у 3,08 раза, p<0,05), проте був статистично вірогідно меншим порівняно з попередніми термінами спостереження ( $p<0,05)$.

Моделювання гострої крововтрати, навпаки, зумовлювало статистично значуще зниження активності каталази в усі терміни спостереження: через 2 год - на 16,0 \%, через 3 год - на 24,4 \%, через 1 добу - на 48,1 \%, через 7 діб - на 34,7 \%, через 14 діб - на 24,3 \% (p<0,05).

Як видно з таблиці 2, показник досягав мінімуму через 1 добу і був істотно нижчим порівняно 3 попередніми термінами спостереження $(p<0,05)$. До 14-ї доби він зростав і через 7 та 14 діб виявився статистично вірогідно вищим, ніж через 2 годй 1 добу спостереження $(p<0,05)$.

Після моделювання гострої крововтрати, ускладненої ішемією-реперфузією кінцівки, активність каталази теж знижувалась та в усі терміни спостереження виявилась істотно меншою, ніж у контрольній групі $(p<0,05)$. Показник досягав мінімуму теж через 1 добу і був на 64,0 \% нижчим порівняно 3 контрольною групою $(\mathrm{p}<0,05)$, а також із попередніми термінами спостереження $(p<0,05)$. До 14-ї доби він зростав, ставав істотно більшим порівняно з попередніми термінами спостереження ( $<<0,05)$, проте залишався на 66,5 \% меншим, ніж у контрольній групі ( $p<0,05)$.

Порівняння дослідних груп між собою показало, що після моделювання гострої крововтрати (2-га дослідна група) активність каталази в усі терміни спостереження була статистично вірогідно нижчою, ніж після моделювання лише ішемії-реперфузії кінцівки (1-ша дослідна група) $\left(p_{1-2}<0,05\right)$. Після нанесення гострої крововтрати, ускладненої ішемією-реперфузією кінцівки (3-тя дослідна група), показник у всі терміни спостереження був істотно меншим, ніж у 1-й $\left(p_{1-3}<0,05\right)$ та 2-й $\left(p_{2-3}<0,05\right)$ дослідних групах.

Активність каталази в 4-й дослідній групі теж у всі терміни спостереження була істотно нижчою, ніж у контрольній групі $(p<0,05)$. Показник досягав мінімальної величини також через 1 і 7 діб посттравматичного періоду та був на 71,9 і 67,1 \% меншим порівняно з контрольною групою $(p<0,05)$.

Додатковий перелом нижньої щелепи теж супроводжувався більшим зниженням активності каталази порівняно $з$ групою, в якій моделювали лише гостру крововтрату й ішемію-реперфрузію кінцівки, проте результат був статистично вірогідним через 1 і 7 діб експерименту (відповідно, на 22,0 та 19,7 \%, $\left.\mathrm{p}_{3-4}<0,05\right)$.

Таким чином, моделювання лише ішемії-реперфузії кінцівки супроводжувалось істотним зниженням у печінці активності СОД на тлі значного зростання активності каталази. Максимум порушень відмічали через 1 добу спостереження. До 14-ї доби активність СОД нормалізувалася, тоді як активність каталази залишалася підвищеною. Отриманий результат свідчив про

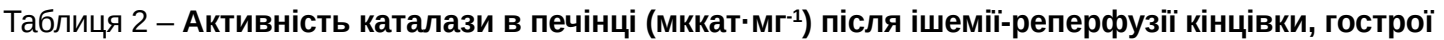
крововтрати і перелому нижньої щелепи (Me (LQ; UQ)) - медіана (нижній та верхній квартилі)

\begin{tabular}{|c|c|c|c|c|c|}
\hline \multirow{2}{*}{ Дослідна група } & \multicolumn{5}{|c|}{ Термін реперфузійного періоду } \\
\hline & 2 год & 3 год & 1-ша доба & 7-ма доба & 14-та доба \\
\hline \multicolumn{6}{|c|}{ Контроль $=0,645(0,606 ; 0,663)(\mathrm{n}=6)$} \\
\hline 1-ша (ішемія-реперфрузія) & $\begin{array}{c}2,35^{\star} \\
(2,24 ; 2,52) \\
(n=6)\end{array}$ & $\begin{array}{c}3,78^{\star 2 r} \\
(3,69 ; 3,89) \\
(n=6)\end{array}$ & $\begin{array}{c}4,12^{\star 2,3 r} \\
(4,09 ; 4,26) \\
(n=6)\end{array}$ & $\begin{array}{c}3,19 * 2 r, 3,1 A \\
(3,10 ; 3,20) \\
(n=6)\end{array}$ & $\begin{array}{c}1,99^{\star 2,3,3,1 \mathrm{~A}, 7 \AA} \\
(1,88 ; 2,16) \\
(\mathrm{n}=6)\end{array}$ \\
\hline 2-га (гостра крововтрата) & $\begin{array}{c}0,54^{\star} \\
(0,53 ; 0,56) \\
(n=6)\end{array}$ & $\begin{array}{c}0,49^{\star} \\
(0,45 ; 0,52) \\
(n=6)\end{array}$ & $\begin{array}{c}0,34^{\star 2,3 r} \\
(0,29 ; 0,36) \\
(n=6)\end{array}$ & $\begin{array}{c}0,42^{* 2,1 A} \\
(0,41 ; 0,45) \\
(n=6)\end{array}$ & $\begin{array}{c}0,49 * 2 r, 1 \mathrm{~A} \\
(0,46 ; 0,49) \\
(\mathrm{n}=6)\end{array}$ \\
\hline $\begin{array}{l}\text { 3-тя (ішемія-реперфрузія+ } \\
\text { гостра крововтрата }\end{array}$ & $\begin{array}{c}0,50^{\star} \\
(0,49 ; 0,51) \\
(n=6)\end{array}$ & $\begin{array}{c}0,32^{\star 2 r} \\
(0,31 ; 0,33) \\
(n=6)\end{array}$ & $\begin{array}{c}0,23^{* 2,35} \\
(0,21 ; 0,24) \\
(n=6)\end{array}$ & $\begin{array}{c}0,26 * 2,3 r \\
(0,23 ; 0,29) \\
(n=6)\end{array}$ & $\begin{array}{c}0,28 * 2 r, 3 r, 1 \mathrm{~A} \\
(0,26 ; 0,30) \\
(n=6)\end{array}$ \\
\hline $\begin{array}{l}\text { 4-та (ішемія-реперфузія+ } \\
\text { гостра крововтрата+ } \\
\text { перелом щелепи }\end{array}$ & $\begin{array}{c}0,46^{*} \\
(0,44 ; 0,48) \\
(n=10)\end{array}$ & $\begin{array}{c}0,30 * 2 r \\
(0,28 ; 0,31) \\
(n=9)\end{array}$ & $\begin{array}{c}0,18^{* 2,35} \\
(0,16 ; 0,20) \\
(n=7)\end{array}$ & $\begin{array}{c}0,21 * 2,3 r \\
(0,19 ; 0,22) \\
(n=7)\end{array}$ & $\begin{array}{c}0,24^{*} \\
(0,24 ; 0,28) \\
(n=6)\end{array}$ \\
\hline $\mathrm{p}_{1-2}$ & $<0,05$ & $<0,05$ & $<0,05$ & $<0,05$ & $<0,05$ \\
\hline$p_{1-3}$ & $<0,05$ & $<0,05$ & $<0,05$ & $<0,05$ & $<0,05$ \\
\hline $\mathrm{p}_{2-3}$ & $<0,05$ & $<0,05$ & $<0,05$ & $<0,05$ & $<0,05$ \\
\hline$p_{3-4}$ & $>0,05$ & $>0,05$ & $<0,05$ & $<0,05$ & $>0,05$ \\
\hline
\end{tabular}


виснаження СОД та компенсаторне зростання активності каталази за умов експерименту. Водночас при гострій крововтраті відмічали виснаження антиоксидантних ензимів - супероксиддисмутази і каталази, що відповідало загальним закономірностям реакції організму на гостру крововтрату [20]. Однак додаткова ішемія-реперфузія кінцівки суттєво поглиблювала порушення антиоксидантного захисту. За цих умов порушення ставали тривалими в часі й не нормалізувалися до 14-ї доби експерименту. Можна припустити, що в патогенезі зазначених порушень мало місце нашарування патогенних механізмів як гострої крововтрати, так й ішемії-реперфузії кінцівки.

Варто відмітити, що спільними ознаками зазначених порушень у групах тварин із гострою крововтратою та її ускладненням ішемією-реперфузією кінцівки були максимальне зниження показників до 1-ї доби спостереження і підвищення до 14-ї доби, яке не досягало рівня контрольної групи. Отже, максимум порушень спостерігали через 1 добу після реперфузії, що має важливе практичне значення стосовно потреби у своєчасних лікувальних заходах.

За умов додаткового нанесення перелому нижньої щелепи відзначали ще більше зниження активності СОД через 1 добу і каталази через 1 та 7 діб порівняно з групою, в якій моделювали лише гостру крововтрату й ішемію-реперфузію кінцівки.

Таким чином, перелом нижньої щелепи поглиблює тяжкість системних порушень, зумовлених гострою крововтратою та ішемією-реперфузією кінцівки. В основі виявлених порушень, з одного боку, лежить специсріка ураження, адже навіть ізольований перелом нижньої щелепи різко погіршує якість життя, стає додатковим джерелом стресу через тимчасове зменшення спроможності споживати їжу природним способом. Крім цього, за даними окремих авторів, ізольований перелом щелепи супроводжується певними системними відхиленнями, характерними для травматичної хвороби [21]. У патогенезі травми нижньої щелепи провідну роль відіграють зростання синтезу медіаторів запалення, посилення лейкоцитарної реакції з утворення активних форм оксигену, що може призвести до активації процесів ліпідної пероксидації, висна- ження ензимної ланки антиоксидантного захисту. За цих умов автори виявили наростання системних порушень з боку органів і тканин, віддалених від місця перелому. Останні, ймовірно, нашаровуються на патогенні механізми гострої крововтрати й ішемії-реперфузії кінцівки та поглиблюють порушення антиоксидантного захисту в печінці, що слід мати на увазі в клініці при розробці заходів системної корекції.

ВИСНОВКИ. 1. Внаслідок двогодинної ішемії та реперфузії кінцівки в печінці суттєво знижується активність супероксиддисмутази з максимумом через 1 добу, яка повертається до рівня контрольної групи через 14 діб. Водночас у всі терміни спостереження підвищеною $€$ активність каталази, що має компенсаторний характер і свідчить про появу в печінці активних форм оксигену.

2. За умов гострої крововтрати активність ензимів антиоксидантного захисту в печінці істотно знижується вже через 2 год експерименту, досягає мінімуму через 1 добу і зростає до 14-ї доби, проте не досягає рівня контрольної групи. Додаткове моделювання ішемії-реперфузії кінцівки на тлі гострої крововтрати супроводжується найбільшим зменшенням величин супероксиддисмутази і каталази в печінці у всі терміни спостереження, що вказує на нашарування патогенних механізмів обох втручань та свідчить про значне посилення прооксидантних механізмів, викликане гіпоксією органа.

3. Додаткове моделювання перелому нижньої щелепи на тлі гострої крововтрати й ішемії-реперфузії кінцівки супроводжується поглибленням порушень ензимної ланки антиоксидантного захисту в печінці. Відмічають суттєво меншу активність супероксиддисмутази через 1 добу і каталази через 1 і 7 діб порівняно з тваринами, яким моделювали гостру крововтрату й ішемію-реперфузію кінцівки, що вказує на вагому патогенну роль травми нижньої щелепи у виснаженні антиоксидантного захисту на системному рівні.

Перспективними вважаємо поглиблення вивчення системних механізмів порушень за умов перелому нижньої щелепи, гострої крововтрати й ішемії-реперфузії кінцівки та розробку патогенетично обґрунтованих засобів корекції. 


\section{СПИСОК ЛІТЕРАТУРИ}

1. Elster E. A. Implications of combat casualty care for mass casualty events / E. A. Elster, K. B. Frank, E. R. Todd // JAMA. - 2013. - 310 (5). - P. 475-476.

2. Snyder D. Efficacy of prehospital application of tourniquets and hemostatic dressings to control traumatic external hemorrhage / D. Snyder, A. Tsou, K. Schoelles. DOT HS 811 999b. - Washington, DC : National Highway Traffic Safety Administration, 2014. - Available at : www. ems.gov.

3. Копчак А. В. Патогенез і принципи лікування вогнепальних поранень щелепно-лицевої ділянки в умовах багатопрофрільного медичного закладу / А. В. Копчак, В. А. Рибак, Ю. І. Марухно // Медицина неотложных состояний. - 2015. - № 7 (70). - С. 94-105.

4. Сірко А. Г. Результати хірургічного лікування бойових вогнепальних черепно-мозкових поранень / А. Г. Сірко // Медицина неотложных состояний. 2017. - № 8 (87). - С. 80-86.

5. Досвід лікування переломів нижньої щелепи 3 використанням назубних дротяних шин / Ю. М. Принда, Е. 3. Красівський, 3. М. Солонинко, Ю. 3. Солонинко // Медицина транспорту України. - 2009. - № 3. C. 23-26.

6. Переломи нижньої щелепи: аналіз частоти виникнення, локалізації та ускладнень / Д. С. Аветіков, К. П. Локес, С. О. Ставицький [та ін.] // Вісн. проблем біології і медицини. -2014. -3 (112), вип. 3. - С. 62-64.

7. Clasper J. C. Limb complications following prehospital tourniquet use / J. C. Clasper, K. V. Brown, P. Hill // J. R. Army. Med. Corps. - 2009. - 155 (3). P. 200-202.

8. Телевяк А. Т. Динаміка показників перекисного окислення ліпідів та антиоксидантного захисту в м'язовій тканині задніх кінцівок щурів при розвитку ішемічно-реперфрузійного синдрому (експериментальне дослідження) / А. Т. Телевяк // Здобутки клініч. і експерим. медицини. - 2018. - № 3. - С. 132-139.

9. Волотовська Н. В. Зміни активності глутатіонової системи внутрішніх органів у перші години експериментального ішемічно-реперфузійного синдрому кінцівки, поєднаного з крововтратою та механічною травмою / Н. В. Волотовська, Т. Кліффр Нхоквара, І. В. Жулкевич // Здобутки клініч. і експерим. медицини. - 2019. - № 1. - С. 23-27.

10. Morsey $\mathrm{H}$. Patients with critical ischemia of the lower limb are at risk of developing kidney dysfunction / H. Morsey, M. Aslam, N. Standfield // Am. J. Surg. 2003. - 185 (4). - P. 360-363.

\section{REFERENCES}

1. Elster, E.A., Frank, K.B., \& Todd, E.R. (2013). Implications of combat casualty care for mass casualty events. JAMA, 310 (5), 475-476. DOI: 10.1001/ jama.2013.167481.

2. Snyder, D., Tsou, A., \& Schoelles, K. (2014). Efficacy of prehospital application of tourniquets and hemostatic dressings to control traumatic external hemorrhage. DOT HS 811 999b. Washington, DC: National Highway Traffic Safety Administration. Retrieved from: www.ems.gov.
11. Concentration decrease of nitric oxide in the postischemic muscle is not only caused by the generation of $\mathrm{O}_{2}^{-}$/ F. Stoffels, F. Lohöfener, M. Beisenhirtz [et al.] // Microsurgery. - 2007. - 27 (6). - P. 565-568.

12. Comparison of changes in markers of muscle damage induced by eccentric exercise and ischemia/ reperfusion / Q. S. Su, J. G. Zhang, R. Dong [et al.] // Scand. J. Med. Sci. Sports. - 2010. - 20 (5). - P. 748-756.

13. Van der Spuy L. Complications of the arterial tourniquet / L. Van der Spuy // South Afr. J. Anaesth Analg. - 2012. - 18 (1). - P. 14-18.

14. Гудима А. А. Антиоксидантно-прооксидантний та цитокіновий баланс у пізній період комбінованої травми в експерименті / А. А. Гудима, Т. В. Кащак, К. В. Шепітько // Світ медицини та біології. - 2019. № 1 (67). - С. 42-47.

15. Кузьмінський І. В. Особливості жовчовидільної фрункції печінки в умовах ішемічно-реперфузійного синдрому кінцівок, закритої травми органів черевної порожнини, ускладненої масивною крововтратою / І. В. Кузьмінський // Актуальні проблеми транспортної медицини. - 2018. - № 4 (54). - С. 148-158.

16. Цимбалюк Г. Ю. Стан добового діурезу нирок в умовах ішемічно-реперфузійного синдрому кінцівок, травми органів черевної порожнини, ускладненої гіповолемічним шоком, та їх поєднання у ранньому періоді травматичної хвороби / Г. Ю. Цимбалюк // Здобутки клініч. і експерим. медицини. -2018. - № 3. C. $163-169$.

17. Щуцька Г. В. Роль політравми у патогенезі відхилень фрункціонального стану організму на тлі перелому нижньої щелепи і гіпокінетичного остеопорозу в ранній період посттравматичного періоду / Г. В. щуцька // Сучасні технології в стоматології : зб. матеріалів наук.-практ. конф. - Тернопіль, 2011. C. 14.

18. Чевари С. Роль супероксиддисмутазы в окислительных процессах клетки и метод определения ее в биологических материалах / С. Чевари, И. Чаба, Й. Сокей // Лаб. дело. - 1985. - № 11. - С. 678-681.

19. Метод определения активности каталазы / М. А. Королюк, Л. И. Иванова, И. Г. Майорова, В. Е. Токарев // Лаб. дело. - 1988. - № 1. - С. 16-19.

20. Jeremy W. Hemorrhagic shock / W. Jeremy // N. Engl. J. Med. - 2018. - 378 (4). - P. 370-379.

21. Проявления травматической болезни при переломах челюстных костей / С. Н. Федотов, В. А. Лызганов, Т. Е. Райхер, И. О. Авдышоев // Север. гос. мед. ун-т. - 2006. - № 4 (прил. 2). - С. 250-252.

3. Kopchak, A.V., Rybak, V.A., \& Marukhno, Yu.I. (2015). Patohenez i pryntsypy likuvannia vohnepalnykh poranen shchelepno-lytsevoi dilianky $v$ umovakh bahatoprofilnoho medychnoho zakladu [Pathogenesis and treatment approaches in gunshot wounds of the maxillofacial area in specialized multidisciplinary hospital]. Meditsina neotlozhnykh sostoyaniy - Emergensy Medicine, 7 (70), 94-105 [in Ukrainian].

4. Sirko, A.H. (2017). Rezultaty khirurhichnoho likuvannia boiovykh vohnepalnykh cherepno-mozkovykh 
poranen [Outcomes of surgical treatment of combat gunshot craniocerebral injuries]. Meditsina neotlozhnykh sostoyaniy - Emergensy Medicine, 8 (87), 80-86 [in Ukrainian].

5. Prynda, Yu.M., Krasivskyi, E.Z., Solonynko, Z.M., \& Solonynko, Yu.Z. (2009). Dosvid likuvannia perelomiv nyzhnoii shchelepy z vykorystanniam nazubnykh drotianykh shyn [An experience of mandibular fractures management with the use of wire arch bars]. Medytsyna transportu Ukrainy - Transport Medicine of Ukraine, 3, 23-26 [in Ukraini].

6. Avetikov, D.S., Lokes, K.P., Stavytskyi, S.O., Yatsenko, I.V., \& Rozkolupa, O.O. (2014). Perelomy nyzhnoi shchelepy: analiz chastoty vynyknennia, lokalizatsii ta uskladnen [Fractures of the mandible: analysis of the frequency of occurrence, localization and complications]. Visnyk problem biolohii i medytsyny - Bulletin of Problems Biology and Medicine, 3, 3 (112), 62-64 [in Ukrainian].

7. Clasper, J.C., Brown, K.V., \& Hill, P. (2009). Limb complications following pre-hospital tourniquet use. J. R. Army Med. Corps., 155 (3), 200-202. DOI: 10.1136/ jramc-155-03-06.

8. Televiak, A.T. (2018). Dynamika pokaznykiv perekysnoho okyslennia lipidiv ta antyoksydantnoho zakhystu $v$ miazovii tkanyni zadnikh kintsivok shchuriv pry rozvytku ishemichno-reperfuziinoho syndromu (eksperymentalne doslidzhennia) [The dynamic of indicators of lipid peroxidation and antioxidant protection in muscle tissue of the hind limbs of the rats in development of the ischemic-reperfusion syndrome (experimental study)]. Zdobutky klinichnoi i eksperymentalnoi medytsyny Achievements of Clinical and Experimental Medicine, 3, 132-139. Retrieved from: https://doi.org/10.11603/18112471.2018.v0.i3.9318 [in Ukrainian].

9. Volotovska, N.V., Nhokwara, T.C., \& Zhulkevych, I.V. (2019). Zminy aktyvnosti hlutationovoi systemy vnutrishnikh orhaniv u pershi hodyny eksperymentalnoho ishemichnoreperfuzinoho syndromu kintsivky, poiednanoho z krovovtratoiu ta mekhanichnoiu travmoiu [Changes in the glutathione system's activity of internal organs in the first hours of experimental limb ischemiareperfusion syndrome, combined with blood loss and mechanical injury]. Zdobutky klinichnoi i eksperymentalnoi medytsyny - Achievements of Clinical and Experimental Medicine, 1, 23-27. DOI 10.11603/1811-2471. 2019.v0.i1.10043.

10. Morsey, H., Aslam, M., \& Standfield, N. (2003). Patients with critical ischemia of the lower limb are at risk of developing kidney dysfunction. Am. J. Surg., 185 (4), 360-363. DOI: 10.1016/s0002-9610(02)01406-x.

11. Stoffels, F., Lohöfener, F., Beisenhirtz, M., Lisdat, F., \& Büttemeyer, R. (2007). Concentration decrease of nitric oxide in the postischemic muscle is not only caused by the generation of O2-. Microsurgery, 27 (6), 565-568. DOI: 10.1002/micr.20403.

12. Su, Q.S., Zhang, J.G., Dong, R., Hua, B., \& Sun, J.Z. (2010). Comparison of changes in markers of muscle damage induced by eccentric exercise and ischemia/reperfusion. Scand. J. Med. Sci. Sports., 20 (5), 748-756. DOI: 10.1111/j.1600-0838.2009.01015.x.

13. Van der Spuy L. (2012). Complications of the arterial tourniquet. South. Afr. J. Anaesth. Analg., 18 (1), 14-18.
14. Hudyma, A.A., Kashchak, T.V., \& Shepitko, K.V. (2019). Antyoksydantno-prooksydantnyi ta tsytokinovyi balans u piznii period kombinovanoi travmy v eksperymenti [Antioxidant-prooxidant and cytokine balance in the late period of combined trauma in the experiment]. Svit medytsyny ta biolohiyi - World of Medicine and Biology, 1 (67), $42-47$ [in Ukrainian].

15. Kuzminskyi, I.V. (2018). Osoblyvosti zhovchovydilnoi funktsii pechinky $v$ umovakh ishemichno-reperfuziinoho syndromu kintsivok, zakrytoi travmy orhaniv cherevnoi porozhnyny, uskladnenoi masyvnoiu krovovtratoiu [Peculiarities of biliary function of the liver in the conditions of ischemic-reperfusion syndrome of the extremities, closed trauma of the abdominal cavity, complicated by massive blood loss]. Aktualni problemy transportnoi medytsyny - Actual Problems of Transport Medicine, 4 (54), 148-158 [in Ukrainian].

16. Tsymbalyuk, H.Yu. (2018). Stan dobovoho diurezu nyrok $v$ umovakh ishemichno-reperfuziinoho syndromu kintsivok, travmy orhaniv cherevnoi porozhnyny, uskladnenoi hipovolemichnym shokom, ta yikh poiednannia u rannomu periodi travmatychnoi khvoroby [Daily urine renal state under ischemic-reperfusion syndrome of limbs, abdominal injury with hypovolemic shock and their combination in the early period of traumatic disease]. Zdobutky klinichnoi i eksperymentalnoi medytsyny Achievements of Clinical and Experimental Medicine, 3 (35), 163-169 [in Ukrainian].

17. Shchutska, G.V. (2011). Rol politravmy u patohenezi vidkhylen funktsionalnoho stanu orhanizmu na tli perelomu nyzhnoi shchelepy i hipokinetychnoho osteoporozu v ranniy period posttravmatychnoho periodu [The role of polytrauma in the pathogenesis of deviations of the functional state of the organism against the background of mandibular fracture and hypokinetic osteoporosis in the early post-traumatic period]. Zbirnyk materialiv naukovo-praktychnoi konferentsii "Suchasni tekhnolohii v stomatolohii" - Collection of materials of the scientific-practical conference "Modern technologies in dentistry". Ternopil [in Ukrainian].

18. Chevari, S., Chaba, I., \& Sokey, Y. (1985). Rol superoksiddismutazy $v$ okislitelnykh protsessakh kletki i metod opredeleniya yeye $v$ biologicheskikh materialakh [The role of superoxide dismutase in the oxidative processes of the cell and the method for its determination in biological materials]. Labolatornoye delo - Laboratory Work, 11, 678-681 [in Russian].

19. Korolyuk, M.A., Ivanova, L.I., Mayorova, I.G., \& Tokarev, V.Ye. (1988). Metod opredeleniya aktivnosti katalazy [Method for determining the activity of catalase]. Labolatornoye delo - Laboratory Work, 1, 16-19 [in Russian].

20. Jeremy, W. (2018). Hemorrhagic Shock. N. Engl. J. Med., 378 (4), 370-379. DOI: 10.1056/NEJMra1705649.

21. Fedotov, S.N., Lyzganov, V.A., Raykher, T.Ye., \& Avdyshoyev, I.O. (2006). Proyavleniya travmaticheskoy bolezni pri perelomakh chelyustnykh kostey [Manifestations of traumatic disease in fractures of the jaw bones]. Severnyy gosudarstvennyy meditsinskiy universitet Northern State Medical University, 4 (2), 250-252 [in Russian]. 


\section{ДИНАМИКА ЭНЗИМНОГО ЗВЕНА АНТИОКСИДАНТНОЙ ЗАЩИТЫ ПОД ВЛИЯНИЕМ ИШЕМИИ-РЕПЕРФУЗИИ КОНЕЧНОСТИ, ОСТРОЙ КРОВОПОТЕРИ И ПЕРЕЛОМА НИЖНЕЙ ЧЕЛЮСТИ}

\section{Резюме}

Вступление. В современном мире значительно возросла распространенность огнестрельных поражений, осложненных острой кровопотерей из конечностей. Применение в этих условиях кровоостанавливающего жгута с максимальным сроком на 2 ч принадлежит к основным мерам спасения раненых на поле боя. В структуре огнестрельных поражений, кроме ранений конечностей, существенно повысилась частота повреждений лицевой части черепа с преимущественным повреждением нижней челюсти. В патогенезе системных проявлений указанных поражений ведущую роль играет усиление процессов липидной пероксидации. Однако влияние ишемии-реперфузии конечности, острой кровопотери и перелома нижней челюсти на состояние энзимного звена антиоксидантной защиты в печени изучено недостаточно.

Цель исследования - выяснить влияние острой кровопотери, двухчасовой ишемии конечности и травмы нижней челюсти на динамику нарушений энзимного звена антиоксидантной защиты в печени в реперфузионный период.

Методы исследования. Эксперименты выполнены на 146 нелинейных крысах-самцах массой 200220 г. Всех животных разделили на 5 групп: контрольную и 4 опытных. Под тиопентал-натриевым наркозом в 1-й опытной группе крысам моделировали ишемию-реперфузию конечности, во 2-й - острую кровопотерю (20 \% от объема циркулирующей крови), в 3-й - эти поражения сочетали, в 4-й группе животным с острой кровопотерей и ишемией-реперфузией конечности дополнительно моделировали перелом нижней челюсти. Через 2 и 3 ч, а также через 1, 7 и 14 суток крыс выводили из эксперимента и в печени определяли активность супероксиддисмутазы и каталазы.

Результаты и обсуждение. Двухчасовая ишемия конечности в реперсузионный период сопровождалась существенным уменьшением активности супероксиддисмутазы с максимумом через 1 сутки, которая возвращалась к уровню контрольной группы через 14 суток. В то же время во все сроки наблюдения повышенной была активность каталазы, что носило компенсаторный характер и свидетельствовало о появлении в печени активных фрорм кислорода. В условиях острой кровопотери активность энзимов антиоксидантной защиты в печени существенно снижалась уже через 2 ч эксперимента, достигала минимума через 1 сутки и возрастала к 14 суткам, однако не достигала уровня контрольной группы. Дополнительное моделирование ишемии-реперфузии конечности на фоне острой кровопотери сопровождалось наибольшим уменьшением величин супероксиддисмутазы и каталазы в печени во все сроки наблюдения, что указывало на наслоение патогенных механизмов обоих вмешательств и свидетельствовало о значительном усилении прооксидантных механизмов, вызванном гипоксией органа. Дополнительное моделирование перелома нижней челюсти на фроне острой кровопотери и ишемии-реперфрузии конечности сопровождалось углублением нарушений энзимного звена антиоксидантной защиты в печени. Отмечали существенно менее низкую активность супероксиддисмутазы через 1 сутки и каталазы через 1 и 7 суток по сравнению с животными, которым моделировали острую кровопотерю и ишемию-реперфузию конечности, что указывало на важную патогенную роль травмы нижней челюсти в истощении антиоксидантной защиты на системном уровне и требовало разработки патогенетически обоснованных средств коррекции.

Вывод. Переломом нижней челюсти углубляет тяжесть системных нарушений, обусловленных острой кровопотерей и ишемией-реперфузией конечности, одним из проявлений которых является существенно большее истощение энзимного звена антиоксидантной защиты в печени через 1 и 7 суток, которое не достигает уровня контрольной группы к 14 суткам.

КЛЮЧЕВЫЕ СЛОВА: перелом нижней челюсти; кровопотеря; жгут; ишемия; реперфузия; печень; антиоксидантная защита. 
I. I. Horban', A. A. Hudyma', O. H. Netsiuk¹, M. A. Pasichnyk ${ }^{2}$ I. HORBACHEVSKY TERNOPIL NATIONAL MEDICAL UNIVERSITY1

DANYLO HALYTSKYI LVIV NATIONAL MEDICAL UNIVERSITY²

\title{
DYNAMICS OF THE ENZYME LINK OF THE ANTIOXIDANT DEFENSE UNDER THE INFLUENCE OF ISCHEMIA-REPERFUSION OF THE LIMB, ACUTE BLOOD LOSS AND FRACTURE OF THE MANDIBLE
}

\begin{abstract}
Summary
Introduction. In the modern world, the prevalence of gunshot injuries complicated by acute blood loss from the extremities has increased significantly. The use of a hemostatic tourniquet under these conditions with a maximum period of 2 hours belongs to the main measures for rescuing the wounded on the battlefield. In the structure of gunshot injuries, despite injuries to the extremities, the frequency of injuries to the facial part of the skull increased significantly, with predominant damage to the lower jaw. In the pathogenesis of the systemic manifestations of these lesions, the leading role is played by the enhancement of lipid peroxidation processes. However, the effect of limb ischemia-reperfusion, acute blood loss and fracture of the lower jaw on the state of the enzyme link of antioxidant defense in the liver has been insufficiently studied.
\end{abstract}

The aim of the study - to elucidate the effect of acute blood loss, two-hour ischemia of the limb and trauma of the lower jaw on the dynamics of violations of the enzyme link of the liver antioxidant defense during the reperfusion period.

Research Methods. The experiments were performed on 146 nonlinear male rats weighing 200-220 g. All animals were divided into five groups: control and four experimental. In the first experimental group of animals, limb ischemia-reperfusion was simulated under thiopenthalonate anesthesia, acute blood loss (20\% of the circulating blood volume) in the second, and these lesions were combined in the third. In the fourth experimental group of animals with acute blood loss and ischemia-reperfusion of the limb, a fracture of the mandible was additionally simulated. After 2 and 3 hours, as well as after 1, 7 and 14 days, the animals were removed from the experiment and the activity of superoxide dismutase (SOD) and catalase was determined in the liver.

Results and Discussion. It was found that two-hour limb ischemia in the reperfusion period is accompanied by a significant decrease in SOD activity with a maximum after 1 day, which returns to the control level after 14 days. At the same time, during all periods of observation, the activity of catalase is increased, which is of a compensatory nature and indicates the appearance of reactive oxygen species in the liver. Under conditions of acute blood loss, the activity of antioxidant defense enzymes in the liver significantly decreases after 2 hours of the experiment, reaches a minimum after 1 day and increases up to 14 days, but does not reach the control level. Additional modeling of limb ischemia-reperfusion against the background of acute blood loss is accompanied by the greatest decrease in SOD and catalase values in the liver at all periods of observation, indicates a layering of pathogenic mechanisms of both interventions and indicates a significant increase in prooxidant mechanisms caused by organ hypoxia. Additional modeling of a fracture of the lower jaw against the background of acute blood loss and ischemia-reperfusion of the limb is accompanied by deepening violations of the enzyme link of antioxidant protection in the liver. A significantly lower level of SOD after 1 day and catalase after 1 and 7 days is noted compared to animals that were simulated with acute blood loss and ischemia-reperfusion of the limb, indicates an important pathogenic role of mandibular injury in the depletion of antioxidant protection at the systemic level and requires the development of pathogenetically substantiated correction means.

Conclusions. A fracture of the mandible deepens the severity of systemic disorders caused by acute blood loss and ischemia-reperfusion of the limb, one of the manifestations of which is a significantly greater depletion of the enzyme link of antioxidant protection in the liver after 1 and 7 days, which does not reach the control level by 14 days.

KEY WORDS: fracture of the lower jaw; blood loss; turnstile; ischemia; reperfusion; liver; antioxidant protection.

Отримано 02.03.21

Адреса для листування: А. А. Гудима, Тернопільський національний медичний університет імені I. Я. Горбачевського МОз України, майдан Волі, 1, Тернопіль, 46001, Україна, e-mail: arsgudyma@gmail.com. 